\title{
The Influence of Brownfields on Urban Economy of a Settlement
}

\author{
ENDEL Stanislav ${ }^{1, a}$, WERNEROVÁ Eva ${ }^{2, b}$ and KUDA František ${ }^{3, c}$ \\ 1,2,3 VSB-TU Ostrava, Faculty of Civil Engineering, Ludvíka Podéště 1875/17, 70833 \\ Ostrava-Poruba \\ astanislav.endel@vsb.cz, ’eva.wernerova@vsb.cz, cfrantisek.kuda@vsb.cz
}

Keywords: Brownfield, urban economy, settlements, Hlučín.

Abstract. Brownfield structures often occupy extensive areas in urban areas of our cities. Owing to this fact, the compactness of built-up area of settlements and their overall urban economy is strongly impaired, which affects adversely primarily the expenses on operation of cities. This paper makes efforts to identify the main factors impairing the urban economy and is related to the existence of brownfields. These factors are then analysed and quantified generally. The data are subsequently applied to the inventory of brownfields carried out in the city of Hlučín and the expenses, resulting from the existence of brownfields in the city spent by the city or by other subjects uselessly, are expressed in numbers.

\section{Introduction}

The adverse influence of brownfields on the amount of operating expenses of our settlements is quite apparent and indisputable. It is logical that in case of the existence of brownfields, there are unused areas in the structure of the city that impair the urban structure of the settlement and cause overall loosening of the ground plan [1,2]. Considering that the investment costs on restoration of brownfields often exceed the investments spent on building of a similar new structure from scratch several times, the revitalization of most of the brownfield objects is not attractive for private investors $[3,4]$. However, these meditations do not take into consideration the operating costs of future facilities on one hand and any other costs connected with the existence of brownfields on the other hand. Owing to this situation, the ground plans of our cities are continuously extended and new farmland is occupied for new building development whereas there are deserted objects in urban residential areas calling for reconstruction and re-use [5,6].

The existence of deserted premises and areas also impair the overall urban economy of our settlements. The term "urban economy" itself has been found in professional literature since the second half of the last century and it can be said, in general, that it is a science dealing with purposeful and efficient spending of funds on building and operation of urban units. In light of urban economy, the ideal settlements are those, the ground plan of which is the most compact without any useless and unused areas [7]. In case of impairment of the settlement compactness, namely the driving distances within settlements are extended and there are inefficiencies in maintenance and operation of traffic infrastructure network and public utilities, which has consequences on public budgets. The question is whether it would not be more purposeful to invest the funds spent uselessly due to the existence of brownfields in regeneration of these areas or to use them for mitigation or elimination of the cost gap and to support private investors in regeneration of the deserted areas. However, the answer to this question is not simple as it interferes with the problem of delimitation of individual areas in which it is invested uselessly and with subsequent determination of a global amount at least.

\section{Factors influencing the urban economy}

As mentioned above, the decision on the extent of urban economy of a settlement is made by the overall compactness of the build-up area and by related travel distances and the amount of built, operated and maintained traffic infrastructure and public utilities [8]. When fixing the amount which is uselessly spent on building and operation of traffic infrastructure and public utilities, it is necessary to specify firstly the lengths of structures of this infrastructure that is operated inefficiently. Here, it 
can be based on the fact that the land of each brownfield is adjoined to a relative length of traffic infrastructure and public utilities which can be measured and categorized during the enumeration of deserted objects and the subsequent global determination of unit prices of construction and maintenance of the infrastructure from available data does not represent a significant problem. The public utilities operating costs may include the losses of media that are growing logically with their increasing lengths.

In case of setting the costs of transport due to increasing travel distances, the situation is a bit more complicated. The calculation of these costs is based on sociological surveys that found out that a common man estimates one hour of his time to approx. $35 \%$ of his hourly wages [9]. Based on the measurement of a section of road adjoining to the brownfield and on the average vehicle speed, it is possible to set the time which drivers spend uselessly by driving round the deserted structure and convert the time to money on the basis of the previous statement. Based on the data from transport census, it is then possible to find out which amounts the drivers spend uselessly on a daily basis. It is necessary to increase these costs with the price of fuels consumed. Here, it is enough to the average vehicle consumption, the length of the road and the average fuel price and then the calculation is not complicated.

\section{Practical application}

For practical application of the indicated facts and for the calculation of the amounts spent uselessly due to the existence of brownfields, the city of Hlučín was selected. It is a city situated in the north-east part of the Czech Republic and it is part of the Ostrava Residential and Industrial Agglomeration.

A detailed analysis of brownfields mapping the deserted areas larger than 0.01 ha was carried out in the city - the influence of smaller brownfields can be neglected. For each brownfield, a length of road adjacent to the land of the deserted area and the corresponding lengths of public utilities were measured. These data were found out from the territorial-analytical background data of the city. In case that the brownfield occurs along one side of the two-directional street build-up area, these lengths are multiplied by the coefficient 0.5 ; in case that the brownfield used is partly, these are multiplied by the coefficient corresponding to the percentage utilization of the deserted area. The position of individual brownfields in graphic is evident from Fig. 1 the analytical results are then indicated in Table 1 and Table 2.

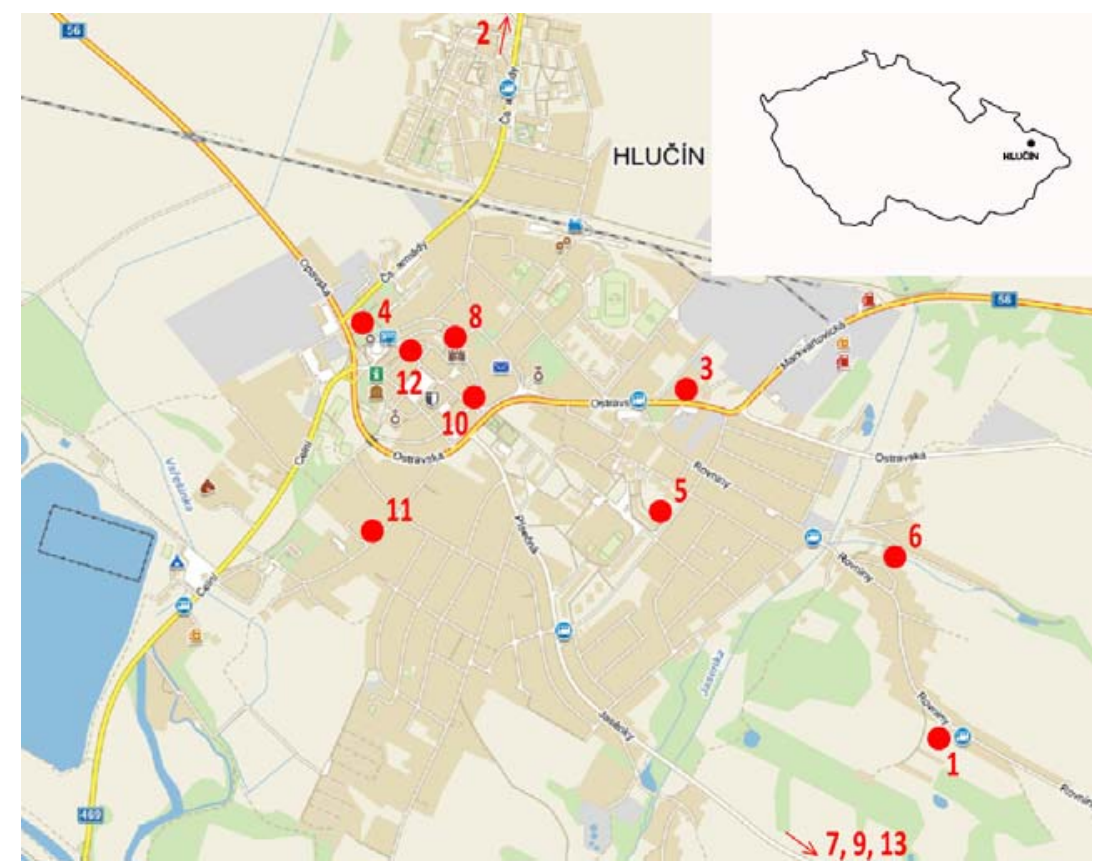

Fig. 1 - Position of brownfields in Hlučín 
Table 1 - Lengths of public utility lines operated uselessly

\begin{tabular}{|c|l|c|c|c|c|c|c|}
\hline \multirow{2}{*}{$\begin{array}{c}\text { Brownfield } \\
\text { number }\end{array}$} & \multicolumn{1}{|c|}{ Name, street } & \multicolumn{3}{|c|}{ Lengths of public utility lines operated uselessly [m] } \\
\cline { 3 - 8 } & & $\begin{array}{c}\text { Water } \\
\text { main }\end{array}$ & Drainage & Gas main & Power line & $\begin{array}{c}\text { Telecom. } \\
\text { line }\end{array}$ & $\begin{array}{c}\text { Hot-water } \\
\text { pipe }\end{array}$ \\
\hline 1 & Kindergarten, Rovniny & 29 & 29 & 29 & 29 & 96 & 0 \\
\hline 2 & Restaurant, Jandova & 25 & 20 & 20 & 25 & 25 & 0 \\
\hline 3 & House, Ostravská & 11 & 11 & 11 & 11 & 34 & 0 \\
\hline 4 & Granary, Opavská & 25 & 24 & 23 & 35 & 17 & 0 \\
\hline 5 & Control station, J. Seiferta & 48 & 48 & 48 & 33 & 25 & 20 \\
\hline 6 & Ruin of house, Boční & 13 & 25 & 25 & 13 & 14 & 0 \\
\hline 7 & Garage with a plot, Malánky & 12 & 20 & 12 & 35 & 36 & 0 \\
\hline 8 & House, Na Valech & 12 & 12 & 7 & 12 & 22 & 0 \\
\hline 9 & House, Spodní & 25 & 25 & 25 & 25 & 26 & 0 \\
\hline 10 & Block of flats, Hrnčíŕská & 7 & 7 & 7 & 7 & 10 & 0 \\
\hline 11 & House, Dlohoveská & 5 & 5 & 5 & 5 & 18 & 0 \\
\hline 12 & House 2, Na Valech & 11 & 11 & 0 & 11 & 11 & 0 \\
\hline 13 & Sweet shop, Osvoboditelů & 12 & 17 & 17 & 17 & 55 & 0 \\
\hline
\end{tabular}

Table 2 - Public utilities operated uselessly

\begin{tabular}{|c|c|c|c|c|c|c|c|}
\hline $\begin{array}{c}\text { Brownfield } \\
\text { number }\end{array}$ & Name, street & $\begin{array}{l}\text { Length of } \\
\text { adjacent } \\
\text { road }[\mathrm{m}]\end{array}$ & $\begin{array}{c}\text { Maximum } \\
\text { speed limit } \\
{[\mathrm{km} / \mathrm{h}]}\end{array}$ & $\begin{array}{l}\text { Number of } \\
\text { vehicles/24 } \\
\text { hours [10] }\end{array}$ & $\begin{array}{c}\text { One vehicle } \\
\text { passage } \\
\text { time [s] }\end{array}$ & $\begin{array}{c}\text { All vehicles } \\
\text { passage } \\
\text { time [h] }\end{array}$ & $\begin{array}{c}\text { Vehicle } \\
\text { kilometres }\end{array}$ \\
\hline 1 & Kindergarten, Rovniny & 29 & 50 & 3771 & 2,1 & 2,19 & 109,36 \\
\hline 2 & Restaurant, Jandova & 20 & 50 & 1248 & 1,4 & 0,50 & 24,96 \\
\hline \multirow{2}{*}{3} & \multirow{2}{*}{ House, Ostravská } & 11 & 50 & 14403 & 0,8 & 3,17 & 158,43 \\
\hline & & 23 & 20 & 214 & 4,1 & 0,25 & 4,92 \\
\hline 4 & Granary, Opavská & 36 & 50 & 8423 & 2,6 & 6,06 & 303,23 \\
\hline \multirow{2}{*}{5} & \multirow{2}{*}{ Control station, J. Seiferta } & 16 & 50 & 1547 & 1,2 & 0,50 & 24,75 \\
\hline & & 13 & 50 & 853 & 0,9 & 0,22 & 11,09 \\
\hline 6 & Ruin of house, Boční & 13 & 20 & 30 & 2,3 & 0,02 & 0,39 \\
\hline 7 & Garage with a plot, Malánky & 11 & 50 & 1784 & 0,8 & 0,39 & 19,62 \\
\hline \multirow{2}{*}{8} & \multirow{2}{*}{ House, Na Valech } & 6 & 20 & 142 & 1,1 & 0,04 & 0,85 \\
\hline & & 6 & 20 & 135 & 1,1 & 0,04 & 0,81 \\
\hline 9 & House, Spodní & 25 & 20 & 148 & 4,5 & 0,19 & 3,70 \\
\hline \multirow{2}{*}{10} & \multirow{2}{*}{ Block of flats, Hrnčířská } & 3 & 20 & 210 & 0,5 & 0,03 & 0,63 \\
\hline & & 4 & 20 & 150 & 0,7 & 0,03 & 0,60 \\
\hline \multirow{2}{*}{11} & \multirow{2}{*}{ House, Dlohoveská } & 5 & 50 & 947 & 0,4 & 0,09 & 4,74 \\
\hline & & 13 & 20 & 15 & 2,3 & 0,01 & 0,20 \\
\hline 12 & House 2, Na Valech & 11 & 20 & 10 & 2,0 & 0,01 & 0,11 \\
\hline \multirow{2}{*}{13} & \multirow{2}{*}{ Sweet shop, Osvoboditelů } & 12 & 50 & 1784 & 0,9 & 0,43 & 21,41 \\
\hline & & 5 & 20 & 20 & 0,9 & 0,01 & 0,10 \\
\hline & TOTAL & 262 & & & & 14,17 & 689,90 \\
\hline
\end{tabular}

The analytical results evident from Table 1 and Table 2 indicate clearly the considerable influence of brownfields on overall urban economy of the city. Several hundreds of metres of public utility lines in the city are operated inefficiently and the results regarding the traffic infrastructure are even more interesting. It was found out that the drivers driving through the city of Hlučín spend more than 14 hours in their vehicles uselessly and they travel almost $700 \mathrm{~km}$ a day.

If we would like to recalculate the indicated data to a financial value, it is necessary to find out an average unit price of construction and operation of individual traffic infrastructure and public utility 
lines and the price of fuels and the average wages of the people living in the city. However, in case of traffic infrastructure and public utilities it is relatively difficult to specify these costs as they fluctuate considerably depending on DN, stress, pressure, etc., in case of traffic, on the road category. The prices for lines of the lowest categories are always indicated and the minimum costs are given in these items, not the average ones [11]. The particular amounts were found out in Czech crowns and converted into euros according to the current exchange rate. The data for the city of Hlučín are presented in Table 3.

Table 3 - Fixing of prices for calculation

\begin{tabular}{|c|c|c|c|}
\hline \multirow{12}{*}{ Public utilities } & \multirow{2}{*}{ Water main } & Price for construction $[€]$ & $110,-$ for $1 \mathrm{~m}$ plastic line DN80 \\
\hline & & Price for maintenance $[€]$ & 1,48 for $1 \mathrm{~m}$ line and year \\
\hline & \multirow{2}{*}{ Drainage } & Price for construction $[€]$ & $354,-$ for $1 \mathrm{~m}$ plastic line DN250 \\
\hline & & Price for maintenance $[€]$ & 3,60 for $1 \mathrm{~m}$ line and year \\
\hline & \multirow{2}{*}{ Gas main } & Price for construction $[€]$ & $89,-$ for $1 \mathrm{~m}$ plastic line DN63 \\
\hline & & Price for maintenance [€] & 1,05 for $1 \mathrm{~m}$ line and year \\
\hline & \multirow{2}{*}{ Power line } & Price for construction $[€]$ & $53,-$ for $1 \mathrm{~m}$ line $3 \times 120$ under $22 \mathrm{kV}$ \\
\hline & & Price for maintenance $[€]$ & 0,59 for $1 \mathrm{~m}$ line and year \\
\hline & \multirow{2}{*}{$\begin{array}{l}\text { Telecommuni- } \\
\text { cation line }\end{array}$} & Price for construction $[€]$ & $6,-$ for $1 \mathrm{~m}$ line coaxial cable \\
\hline & & Price for maintenance $[€]$ & 0,11 for $1 \mathrm{~m}$ line and year \\
\hline & \multirow{2}{*}{ Hot-water pipe } & Price for construction $[€]$ & $290,-$ for $1 \mathrm{~m}$ line $2 \times \mathrm{DN} 100$ \\
\hline & & Price for maintenance $[€]$ & 3,14 for $1 \mathrm{~m}$ line and year \\
\hline \multirow{2}{*}{$\begin{array}{l}\text { Traffic } \\
\text { infrastructure }\end{array}$} & \multirow[t]{2}{*}{ Local roads } & Price for construction $[€]$ & $\begin{array}{c}335,- \text { for } 1 \mathrm{~m} \text { of bitumen road, } 7 \mathrm{~m} \\
\text { wide }\end{array}$ \\
\hline & & Price for maintenance $[€]$ & 3,43 for $1 \mathrm{~m}$ line and year \\
\hline \multicolumn{3}{|c|}{ Average vehicle fuel consumption [12] } & $6,21 / 100 \mathrm{~km}$ \\
\hline \multicolumn{3}{|c|}{ Average fuel price [13] } & $1,11 / 11$ \\
\hline \multicolumn{3}{|c|}{ Average gross wage in the region [14] } & $870,-$ \\
\hline
\end{tabular}

Based on the data in Tables 1, 2 a 3 and on previously indicated facts, it is possible to make a simple calculation and fix which amount of funds is spent annually in the city additionally due to the existence of brownfields. Results for traffic infrastructure and public utilities are indicated in Table 4.

Table 4 - Enumeration of costs connected with the existence of brownfields - traffic infrastructure and public utilities

\begin{tabular}{|c|c|c|c|c|c|}
\hline & $\begin{array}{c}\text { Unit price for } \\
\text { construction [€] }\end{array}$ & $\begin{array}{c}\text { Unit price for } \\
\text { operation and } \\
\text { maintenance } \\
\text { [€/year] }\end{array}$ & Length of line & $\begin{array}{c}\text { Total price for } \\
\text { construction [€] }\end{array}$ & $\begin{array}{c}\text { Total price for } \\
\text { operation and } \\
\text { maintenance } \\
\text { [€/year] }\end{array}$ \\
\hline Water main & 110 & 1,48 & 235 & 25850 & 347,8 \\
\hline Drainage & 354 & 3,6 & 254 & 89916 & 914,4 \\
\hline Gas main & 89 & 1,05 & 229 & 20381 & 240,45 \\
\hline Power line & 53 & 0,59 & 258 & 13674 & 152,22 \\
\hline $\begin{array}{c}\text { Telecommu- } \\
\text { nication line }\end{array}$ & 6 & 0,11 & 389 & 2334 & 42,79 \\
\hline $\begin{array}{c}\text { Hot-water } \\
\text { pipe }\end{array}$ & 290 & 3,14 & 20 & 5800 & 62,8 \\
\hline Local roads & 335 & 3,43 & 262 & 87770 & 898,66 \\
\hline TOTAL & & & & $\mathbf{2 4 5 7 2 5}$ & $\mathbf{2 6 5 9 , 1 2}$ \\
\hline
\end{tabular}


Based on the results indicated in Table 4, it is evident that in case of regeneration of Hlučín's brownfields, almost $€ 250,000$ would be saved for the construction of traffic infrastructure and public utilities and another approx. $€ 2,700$ for the administration of this infrastructure would be utilized purposefully and adequately every year.

In case of costs that are covered in most cases by private persons, i.e. by users of the cars passing through, the calculation is very simple. Based on the presented data, it is possible to find out that costs for 100 kilometres covered are on average amounting to $€ 6.68$ and if the drivers travel uselessly $689.90 \mathrm{~km}$ a day, this means that due to the existence of deserted areas in the city, fuels for $€ 46.82$ are consumed annually and then the amount ascends to almost $€ 16,800$. If we take into account also the lost time of the drivers and if we come out of the above given presumption that the average man estimates an hour of his time to $35 \%$ of his average hourly wages, we will get interesting results as well. If we consider 170 worked hours a month, the average gross hourly wages are $€ 5.11$ whereas $35 \%$ of this sum is $€ 1.79$. The overall lost time of the drivers per day can be evaluated by the amount of $€ 25.39$, then this sum is more than $€ 9,200$ annually. In this connection, it is necessary to point out that we reckon with only one man per car in these meditations. However, more people may travel in their vehicles and this sum could be even higher though it can be expected that the increase would not be so dramatic due to average occupancy of the vehicles. When adding the amounts for consumed fuels and lost time, we will get the sum of $€ 71.42$ daily and $€ 26,066$ annually. If we add the price for maintenance of traffic infrastructure and public utilities, the aggregate annual amount of those used inefficiently is $€ 28,725$ with the fact that $9.26 \%$ thereof is covered from public budgets and the rest is paid by private persons.

Finally, it is necessary to state that the mentioned funds will not be saved by regeneration of the said brownfields; these areas cannot be taken out of the urban structure and "cut short" the city in this way; these funds will only be used much more efficiently and purposefully. The exception is constituted by the costs for the acquisition of structures of traffic infrastructure and public utilities. These costs will be saved in case of comparison of the regeneration of brownfields and construction of similar objects from scratch using the comparable types of infrastructure.

\section{Conclusion}

Based on the above mentioned procedure, it is possible to quantify the costs spent uselessly that results from the existence of brownfields in every city, namely on the basis of the detailed analysis of brownfields and by fixing several cost prices. It is seen on the example of Hlučín that these are not small sums at all and the total sum can reach the costs for regeneration of the selected brownfield in several years.

Nevertheless, it is necessary to point out that overall results are relatively strongly dependent on the recognized unit prices and that these prices vary every year quite significantly. The example mentioned here indicates only the procedure for the calculation and perhaps the way how to fix the overall costs; however, the presented prices are rather of an informative nature and they must be put more precisely before application of the given procedure to any other city.

Nevertheless, based on the data presented, it can be stated that the investments in regeneration of the majority of brownfields pay off in the long run as we will obtain savings in uselessly spent funds by the regeneration. It is a pity that the data are almost never taken into account in meditations upon regeneration of brownfields.

\section{Acknowledgements}

The works were subsidized from the funds for conceptual development of sciences, research and innovations for 2015 allocated to VŠB-TUO by the Ministry of Education, Youth and Sports of the Czech Republic. 


\section{References}

[1] Ch. Couch, Ch. Fraser and S. Percy: Urban regeneration in Europe. Blackwell Science (2003). ISBN 0632058412.

[2] D. Edwards: Best practice guidance for sustainable brownfield regeneration. Rescue (2005). ISBN 0-9547474-0-2.

[3] A. Alberini, et al.: The Role of Liability, Regulation and Economic Incentives in Brownfield Remediation and Redevelopment: Evidence from Surveys of Developers. (Regional Science and Urban Economics, USA 2005).

[4] R. Hise and A. C. NELSON. Urban Brownfields: Strategies for Promoting Urban Brownfield Re-Use At the State and Local Level. (Economic Development Review, Great Britain 1999).

[5] F. Ellerbusch: Brownfields: Risk, Property, and Community Value. (Local Environment, USA 2006).

[6] A. Ritchie and T. Randálů: Sustainable urban design: an environmental approach. Taylor \& Francis, (2009). ISBN 9780415447829.

[7] G. Maier and F. Tődtling: Regionálna a urbanistická ekonomika: teória lokalizácie a priestorová štruktúra. Elita (1997). ISBN 80-8044-044-1.

[8] A. Amekudzi and I. Fomunung: Integrating Brownfields Redevelopment with Transportation Planning. (Journal of Urban Planning \& Development, USA 2004).

[9] K. Maier and J. Čtyřoký. Ekonomika územního rozvoje. Grada (2000). ISBN 80-7169-644-7.

[10] Information on http://scitani2010.rsd.cz/pages/informations/default.aspx.

[11] Information on http://www.uur.cz.

[12] Information on http://www.spotreby.cz.

[13] Information on http://www.ccs.cz.

[14] Information on http://www.csu.cz. 